\title{
The effects of occupational lead exposure on selected inflammatory biomarkers
}

\author{
Vugar Ali Turksoy ${ }^{1}$, Lutfiye Tutkun ${ }^{2}$, Servet Birgin Iritas ${ }^{3}$, Meside Gunduzoz $^{4}$, and Serdar Deniz ${ }^{5}$ \\ ${ }^{1}$ Department of Public Health, Yozgat Bozok University Faculty of Medicine, Yozgat, Turkey \\ ${ }^{2}$ Department of Biochemistry, Yozgat Bozok University Faculty of Medicine, Yozgat, Turkey \\ ${ }^{3}$ The Council of Forensic Medicine, Ministry of Justice, Ankara, Turkey \\ ${ }^{4}$ Department of Family Medicine, Ankara Occupational Diseases Hospital, Ankara, Turkey \\ ${ }^{5}$ Provincial Health Directorate, Malatya, Turkey
}

[Received in October 2018; Similarity Check in October 2018; Accepted in March 2019]

In exposure to toxic metals such as lead, determining lead and cytokine levels (IL-6, IL-10, and TNF- $\alpha$ ) is essential for early detection of diseases. The aim of this study was to develop an model for early detection of inflammation and onset of atherosclerosis in the absence of clinical findings in young workers, which could help physicians take timely an action and start treatment. This study included 49 metal workers exposed to lead occupationally and 50 unexposed administrative workers (controls) who underwent immunological analysis for cytokines (IL-6, IL-10, and TNF- $\alpha$ ) and atherosclerosis markers (h-FABP and VCAM-1), toxicological analysis for lead, and routine biochemical analysis (ALT, AST, creatinine) at the Ankara Occupational and Environmental Diseases Hospital in 2017. Lead levels correlated with IL-6, IL-10, and TNF- $\alpha(r=0.469, r=0.521$ and $r=0.279$, respectively, $\mathrm{p}<0.01)$ but did not significantly affect $h-F A B P$ and VCAM-1 levels.

KEY WORDS: atherosclerosis; cytokines; h-FABP; IL-6; IL-10; TNF- $\alpha$; VCAM-1

Occupational and environmental exposure to metals and metalloids can cause many pathological conditions, including immunotoxicity. Research has shown that the most important mechanism underlying diseases associated with lead exposure is inflammation (1-3). Inflammation also plays a major role in the development of atherosclerosis $(4,5)$. It acts at all stages, including fatty streak, plaque formation, and plaque disruption (6). Since the 1970s, atherosclerosis has been considered as an immunoinflammatory disease, in whose development cytokines play a key role (7). Cytokines are small proteins primarily involved in cellular signalling pathways and intracellular inflammatory and immune responses (8). Several mechanisms have been proposed to explain how lead may cause or aggravate atherosclerosis: by inhibiting endothelial physiological functions, by impairing angiogenesis, by inactivating nitric oxide, and by increasing inflammation through cytokines $(9,10)$.

Lead exposure has always been an actual topic, environmentally and occupationally. Numerous scientific studies have shown the link between lead exposure and cardiovascular abnormalities such as coronary artery disease, atherosclerosis, stroke, peripheral arterial disease, and arterial hypertension (11-14). Many have also established that lead exposure is closely related to inflammation $(2,15,16)$ and that it increases pro-

Corresponding author: Vugar Ali Turksoy, Department of Public Health, Yozgat Bozok University Faculty of Medicine, Yozgat, Turkey e-mail:v.aliturksoy@bozok.edu.tr;dr.turksoy@gmail.com inflammatory cytokine production, including tumour necrosis factor- $\alpha$ (TNF- $\alpha$ ), interleukin-6 (IL-6), and interleukin-10 (IL-10) $(17,18)$.

To improve atherosclerosis risk prediction, recent investigations have focused on the simultaneous use of multiple biomarkers. Besides cytokines, some other biomarkers could help to establish the adverse effects of occupational exposure to lead. In this study we evaluated the potential of the vascular cell-adhesion molecule-1 (VCAM-1) and the heart-type fatty acid binding protein (h-FABP) as predictive markers of lead-related atherosclerosis. VCAM-1 is an immunoglobulin-like adhesion molecule that promotes monocyte adhesion and accumulation on the vessel wall (19) and is critical to the development of atherosclerotic lesions in animal models (20). Fatty acid binding proteins (FABPs) play a key role in the transportation of fatty acids and lipophilic molecules through the cell membrane. As an intra-cardiac protein, h-FABP has been shown to activate inflammation, besides indicating myocardial injury (21). There are several studies that link this protein to chronic clinical conditions, including atherosclerosis $(22,23)$.

In our study, we aimed to determine the IL-6, IL-10, TNF- $\alpha$, h-FABP, and VCAM-1 levels in lead-exposed workers to find their association with blood lead levels and standard haematological and biochemical markers commonly used to establish adverse effects of occupational lead exposure that point to increased risk of inflammation and atherosclerosis. 


\section{PARTICIPANTS AND METHODS}

\section{Study population and blood sampling}

The study included 49 metal recycling workers exposed to lead through their occupation and 50 unexposed administrative workers, who served as control. The inclusion criteria for the exposed group were high blood lead levels (BLL $>10 \mu \mathrm{g} / \mathrm{dL})(24)$ and active job in melting for more than six months. Persons with acute infections, chronic lung disease, diabetes mellitus, diagnosed coronary vascular disease, hypertension, rheumatic diseases, or cancer were excluded from the study.

Both groups were examined and their blood tested at the Ankara Occupational and Environmental Diseases Hospital in 2017. Blood samples (one per participant, totalling 99) were taken for immunological, toxicological, and standard haematological/biochemical analysis at the end of the work shift of the last day of work week following the American Conference of Governmental Industrial Hygienists (ACGIH) industrial toxicological standards (25). All procedures followed the 1964 Helsinki Declaration and its later amendments. All participants gave their informed consent to participate. The study protocol was approved by the Clinical Research Ethics Committee of the Yozgat Bozok University Faculty of Medicine (approval no. 12.10.2016/70).

\section{Collection of biological samples and laboratory analysis}

Biomarkers were analysed in the sera separated from blood samples by centrifugation at $1500 \mathrm{rpm}$ for $10 \mathrm{~min}$ and then transferred to $2 \mathrm{~mL}$ Eppendorf tubes and frozen to $-20{ }^{\circ} \mathrm{C}$. Frozen samples were transferred to the Occupational and Environmental Toxicology Laboratory of the Yozgat Bozok University Science and Technology Application and Research Center (BILTEM) using a cold chain system and stored at $-20{ }^{\circ} \mathrm{C}$ until analysis.

For IL-6, IL-10, TNF- $\alpha$, h-FABP, and VCAM-1 analyses we used the respective ELISA kits: KAP1261, KAP1321, KAP1751 (DIAsource ImmunoAssays SA, Louvain-laNeuve, Belgium), DZE201121214, and DZE201120204 (Shanghai Sunred Biological Technology Co., Shanghai, China) and prepared the samples following manufacturer's instructions for each kit. The samples were then placed on microplates and fed to a CLARIOstar ELISA plate reader (BMG LABTECH, Ortenberg, Germany). The wavelength was set at $450 \mathrm{~nm}$. Five-point calibration curves were used for all biomarker measurements. The $\mathrm{r}^{2}$ values of the calibration curves were 0.9994, 0.9994, 0.9992, 0.9995, and 0.9997 , respectively. For verification we used standards that come with the kits. Linear regression was implemented to obtain all biomarker results.

For lead analysis we took $1 \mathrm{~mL}$ of the whole blood sample, placed in a Teflon tube, added $5 \mathrm{~mL}$ of suprapuregrade $65 \%$ nitric acid $\left(\mathrm{HNO}_{3}\right.$, Merck, Darmstadt, Germany) and $5 \mathrm{~mL}$ of ultrapure water (Millipore Direct-Q3, Merck), and digested in a Milestone Start D microwave digestion system (Sorisole, Italy). The digested samples were then transferred to $50 \mathrm{~mL}$ polypropylene tubes, added deionised to obtain the total volume of $20 \mathrm{~mL}$, and stored at $+4{ }^{\circ} \mathrm{C}$ until analysis (26). Lead levels were determined with inductively coupled plasma mass spectrometry (ICP-MS; iCAP Qc model, Thermo Scientific, Waltham, MA, USA). The method was validated with the certified reference material (CRM-Seronorm ${ }^{\mathrm{TM}}$ Trace Elements Whole Blood L-2, Billingstad, Norway) and the $\mathrm{r}^{2}$ value of the calibration curve was 0.9998 .

\section{Statistical analysis}

For statistical analysis we used the Statistical Package for Social Sciences version 24.0 (SPSS Inc., Chicago, IL, USA). The Mann-Whitney U test was used to determine differences in the main parameters between the control and exposed group (Table 1). The Pearson test was used to determine 2-tailed correlations between cytokine levels and toxicological-biochemical variables in both groups. Regression analysis was used to understand which of the independent variables correlated with lead levels as the dependent variable. The levels of statistical significance were set at $\mathrm{p}<0.05$ and $\mathrm{p}<0.01$.

\section{RESULTS}

Table 1 shows the differences in the main parameters between the groups. The two groups significantly differed in WBC, AST, Pb, IL-6, IL-10, and TNF- $\alpha$ levels but not in h-FABP and VCAM-1 cytokine levels. The exposed workers also had shorter working experience than control, most likely because of health problems at an early age.

The Pearson correlation (Table 2) showed high positive correlations between $\mathrm{Pb}$ levels and the IL-6, IL-10, and TNF- $\alpha$ cytokine levels $(r=0.469, r=0.521$, and $r=0.279$, respectively, $\mathrm{p}<0.01)$. $\mathrm{Pb}$ also positively correlated with WBC levels $(\mathrm{r}=0.252, \mathrm{p}<0.01)$ and negatively with HGB levels $(\mathrm{r}=-0.200, \mathrm{p}<0.05)$. Creatinine negatively correlated with IL-10 and TNF-a $(r=-0.208$ and $r=-0.246$, respectively, $\mathrm{p}<0.01)$, and AST negatively correlated with IL-10 $(\mathrm{r}=-0.020$, $\mathrm{p}<0.05)$.

Regression analysis (Table 3) did not establish any significant effects of $\mathrm{Pb}$ on VCAM-1 or h-FABP levels, but did find a significant correlation between $\mathrm{Pb}$ and the cytokines. It accounted for the $7.8 \%$ change in TNF- $\alpha$ levels, the $27.2 \%$ change in the IL-10 levels, and the $22.0 \%$ change in the IL-6 levels $(\mathrm{p}<0.05)$.

\section{DISCUSSION}

With this study we aimed to develop a model for the early detection of inflammation and onset of atherosclerosis 
Table 1 Differences in parameters between control and exposed groups

\begin{tabular}{|c|c|c|c|c|c|c|c|c|}
\hline \multirow[b]{3}{*}{ Parameter } & \multicolumn{6}{|c|}{ Groups } & \multirow{2}{*}{\multicolumn{2}{|c|}{ Significance }} \\
\hline & \multicolumn{3}{|c|}{ Control } & \multicolumn{3}{|c|}{ Exposed } & & \\
\hline & Mean & Median & Range & Mean & Median & Range & $\begin{array}{c}\text { Mann- } \\
\text { Whitney U } \\
\text { test }\end{array}$ & $\mathbf{p}$ \\
\hline Age (years) & 42.00 & 40.00 & $33.5-51.25$ & 32.57 & 31.00 & $28.00-37.00$ & 523.50 & $<0.001$ \\
\hline BMI $\left(\mathrm{kg} / \mathrm{m}^{2}\right)$ & 27.67 & 27.13 & $25.69-29.02$ & 26.65 & 26.82 & $25.51-27.73$ & 1054.50 & 0.233 \\
\hline Work duration (years) & 13.74 & 8.00 & $5.75-24.00$ & 3.29 & 2.00 & $1.00-2.00$ & 326.50 & $<0.001$ \\
\hline WBC & 7.28 & 7.02 & $6.01-8.44$ & 8.12 & 7.70 & $7.10-9.43$ & 921.50 & 0.034 \\
\hline $\operatorname{HGB}(\mathrm{g} / \mathrm{dL})$ & 15.47 & 15.40 & $14.90-16.42$ & 14.91 & 15.30 & $14.55-15.85$ & 976.00 & 0.081 \\
\hline $\operatorname{HCT}(\%)$ & 45.87 & 45.75 & $43.55-48.25$ & 45.04 & 45.00 & $43.35-47.15$ & 1094.50 & 0.361 \\
\hline $\operatorname{PLT}\left(10^{3} / \mu \mathrm{L}\right)$ & 233.46 & 238.00 & $209-267$ & 235.98 & 229.00 & $186.00-282.00$ & 1224.00 & 0.994 \\
\hline ALT (U/L) & 26.68 & 22.00 & $17-28$ & 24.06 & 19.00 & $14.00-33.00$ & 1106.00 & 0.404 \\
\hline $\operatorname{AST}(\mathrm{U} / \mathrm{L})$ & 21.60 & 20.00 & $17-25$ & 19.14 & 19.00 & $15.00-22.00$ & 963.00 & 0.046 \\
\hline Creatinine $(\mu \mathrm{mol} / \mathrm{L})$ & 0.83 & 0.82 & $0.77-0.90$ & 0.81 & 0.80 & $0.75-0.90$ & 1057.00 & 0.235 \\
\hline $\mathrm{Pb}(\mu \mathrm{g} / \mathrm{dL})$ & 2.73 & 1.55 & $1-3.02$ & 21.44 & 19.30 & $16.10-26.95$ & 0.000 & $<0.001$ \\
\hline VCAM-1 (ng/mL) & 8.55 & 7.58 & $4.59-11.14$ & 8.17 & 7.66 & $4.80-9.28$ & 1204.00 & 0.883 \\
\hline h-FABP (ng/mL) & 2.52 & 1.82 & $1.53-3.01$ & 2.60 & 1.81 & $1.61-3.26$ & 1191.00 & 0.812 \\
\hline TNF- $\alpha(\mathrm{pg} / \mathrm{mL})$ & 3.70 & 4.43 & $1.97-4.94$ & 4.76 & 4.65 & $4.13-5.23$ & 871.50 & 0.013 \\
\hline IL-10 (pg/mL) & 33.23 & 36.54 & $27.77-39.58$ & 43.69 & 41.92 & $39.27-45.97$ & 452.00 & $<0.001$ \\
\hline IL-6 (pg/mL) & 24.38 & 20.49 & $16.42-27.73$ & 49.34 & 49.00 & $34.70-59.08$ & 348.00 & $<0.001$ \\
\hline
\end{tabular}

Significant differences are in boldface $(\mathrm{p}<0.05$ or $\mathrm{p}<0.001)$

Abbreviations: BMI - body mass index; WBC - white blood cells; HGB - haemoglobin; HCT - haematocrit; PLT - platelets; ALT - alanine aminotransferase; AST - aspartate aminotransferase; VCAM-1 - vascular cell-adhesion molecule-1; h-FABP - heart-type fatty acid-binding protein; TNF- $\alpha$ - tumour necrosis factor alpha; IL-10 - interleukin 10; IL-6 - interleukin 6

in young workers exposed to lead in the absence of clinical signs and symptoms. Occupational lead exposure significantly reflected on the increased levels of proinflammatory cytokines IL-6, IL-10, and TNF- $\alpha$ but did not significantly affect h-FABP and VCAM. A study with similar age groups reported BLLs of $9.70 \pm 4.20 \mu \mathrm{g} / \mathrm{dL}$ in pottery workers and $21.70 \pm 8.80 \mu \mathrm{g} / \mathrm{dL}$ in foundry workers (27). Both groups of exposed workers had significantly higher plasma IL-10 and TNF- $\alpha$, but not IFN- $\gamma$, IL-2, IL-4, and IL-6. In contrast, another study (2) reported lower TNF- $\alpha$ levels in lead-exposed battery plant workers than controls, but not significantly ( $\mathrm{p}>0.05$ ). An environmental study (28) that determined the effects of lead on human semen reported higher IL-7, IL-10, IL-12, and TNF- $\alpha$ levels in a group highly exposed to lead, while the levels of IL-1 $\beta$, IL-2, IL-4, IL-6, IL-8, and IFN- $\gamma$ did not change significantly.

The strong correlations between BLLs and the levels of IL-6, IL-10, and TNF- $\alpha$ in our study evidence the inflammatory effect of lead, which may lead to the onset of atherosclerosis, even though clinical signs and symptoms may be absent in young people at the early stage. Our group was probably too young to show a correlation between lead exposure and h-FABP and VCAM-1. h-FABP is a novel biomarker for acute myocardial injury and infarct $(29,30)$ and a predictor of short-term mortality (31). In atherosclerosis and inflammation studies about VCAM, there are conflicting reports about its predictive potential for early atherosclerosis. An old study (32) on human coronary arteries from explanted hearts showed no correlation between VCAM-1 and underlying inflammatory cells. Other studies (33-36) have shown that VCAM is a sensitive biomarker for the acute coronary syndrome, but the absence of significant correlations with the cytokines and BLL in our study suggest that it cannot be used as a predictor of atherosclerosis associated with occupational exposure to lead.

One limitation of our study was that we did not analyse serum nitric oxide levels or other oxidative stress parameters mediating lead toxicity. Knowing these parameters could have helped us to better understand the cytotoxic effects of lead and better interpret the observed inflammation and atherosclerosis marker findings. Hopefully one of our future studies will address this issue.

\section{Conflicts of interest}

None to declare.

\section{Acknowledgements}

This study was supported by the Yozgat Bozok University Scientific Research Foundation (grant No. 6602c-TF/17-96). 


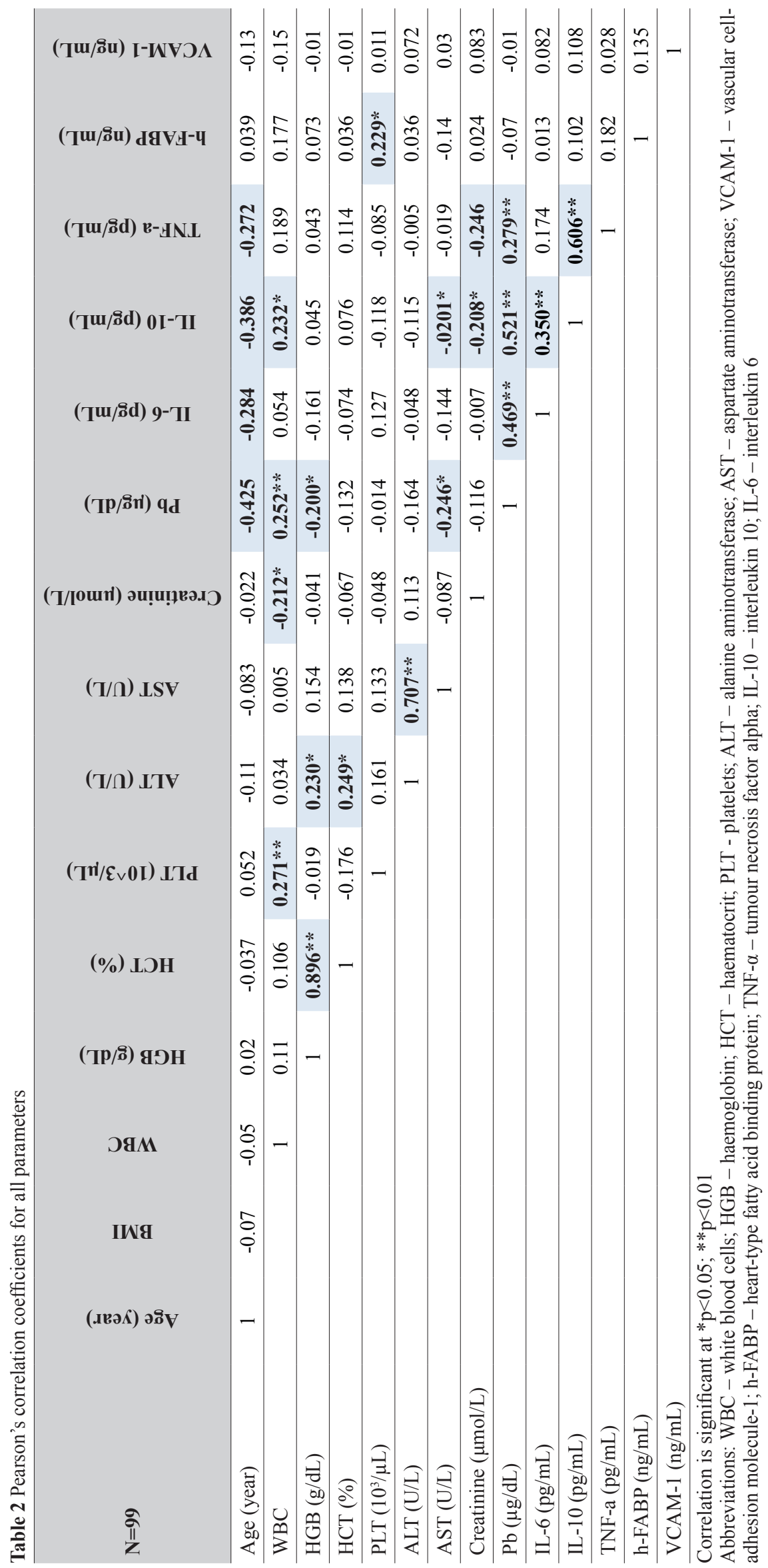


Table 3 Regression analysis for $\mathrm{Pb}$ and independent variable

\begin{tabular}{lcccc}
$\begin{array}{l}\text { Dependent } \\
\text { variable }\end{array}$ & F & Beta & $\mathbf{t}$ & $\mathbf{R}^{2}$ \\
\hline IL-6 & $28.720 *$ & 0.469 & $5.359 *$ & 0.220 \\
\hline IL-10 & $38.042 *$ & 0.521 & $6.168 *$ & 0.272 \\
\hline TNF-a & $8.594 *$ & 0.279 & $2.932 *$ & 0.078
\end{tabular}

Abbreviations: TNF- $\alpha$ - tumour necrosis factor alpha; IL-10 interleukin 10; IL-6 - interleukin 6

\section{REFERENCES}

1. Shen X, Lee K, König R. Effects of heavy metal ions on resting and antigenactivated $\mathrm{CD} 4(+) \mathrm{T}$ cells. Toxicology 2001;169:67-80. doi: 10.1016/S0300-483X(01)00483-8

2. Metryka E, Chibowska K, Gutowska I, Falkowska A, Kupnicka P, Barczak K, Chlubek D, Baranowska-Bosiacka I. Lead $(\mathrm{Pb})$ Exposure enhances expression of factors associated with inflammation Int J Mol Sci 2018;19:1813 doi: 10.3390/ijms19061813

3. Mrowicki J, Mrowicka M, Dziki A, Dziki L, Majsterek I. Etiopathogenesis of inflammatory bowel diseases. Biomark J 2018;4:8. doi: 10.21767/2472-1646.100046

4. Libby P, Ridker PM, Hansson GK; Leducq Transatlantic Network on Atherothrombosis. Inflammation in atherosclerosis: from pathophysiology to practice. J Am Coll Cardiol 2009;54:2129-38. doi: 10.1016/j.jacc.2009.09.009

5. Falk E. Pathogenesis of atherosclerosis. J Am Coll Cardiol 2006;47(Suppl):C7-C12. doi: 10.1016/j.jacc.2005.09.068

6. Tedgui A, Mallat Z. Cytokines in atherosclerosis: pathogenic and regulatory pathways. Physiol Rev 2006;86:515-81. doi: 10.1152/physrev.00024.2005

7. Ross R, Glomset JA. The pathogenesis of atherosclerosis. N Engl J Med 1976;295:369-77. doi: 10.1056/ NEJM197608122950707

8. Boulay JL, O'Shea JJ, Paul WE. Molecular phylogeny within type I cytokines and their cognate receptors. Immunity 2003;19:159-63. doi: 10.1016/S1074-7613(03)00211-5

9. Navas-Acien A, Guallar E, Silbergeld E, Rothenberg SJ. Lead exposure and cardiovascular disease: a systematic review. Environ Health Perspect 2006;115:472-82. doi: 10.1289/ ehp. 9785

10. Aoki Y, Brody DJ, Flegal KM, Fakhouri TH, Parker JD, Axelrad DA. Blood lead and other metal biomarkers as risk factors for cardiovascular disease mortality. Medicine (Baltimore) 2016;95:e2223. doi: 10.1097 MD.0000000000002223

11. Lustberg M, Silbergeld E. Blood lead levels and mortality. Arch Intern Med 2002;162:2443-9. doi: 10.1001/ archinte.162.21.2443

12. Menke A, Muntner P, Batuman V, Silbergeld EK, Guallar E. Blood lead below $0.48 \mu \mathrm{mol} / \mathrm{L}(10 \mu \mathrm{g} / \mathrm{dL})$ and mortality among US adults. Circulation 2006;114:1388-94. doi: 10.1161/CIRCULATIONAHA.106.628321

13. Lanphear BP, Rausch S, Auinger P, Allen RW, Hornung RW. Low-level lead exposure and mortality in US adults: a population-based cohort study. Lancet Public Health 2018;3:e177-84. doi: 10.1016/S2468-2667(18)30025-2

14. Krocova Z, Macela A, Kroca M, Hernychova L. The immunomodulatory effect(s) of lead and cadmium on the cells of immune system in vitro. Toxicol In Vitro 2000;14:3340. doi: 10.1016/S0887-2333(99)00089-2
15. Flohé SB, Brüggemann J, Herder C, Goebel C, Kolb H. Enhanced proinflammatory response to endotoxin after priming of macrophages with lead ions. J Leukoc Biol 2002;71:417-24. doi: 10.1189/jlb.71.3.417

16. Huo Y, Hafezi-Moghadam A, Ley K. Role of vascular adhesion molecule- 1 and fibronectin connecting segment-1 in monocyte rolling and adhesion on early atherosclerotic lesion. Circ Res 2000;87:153-9. doi: 10.1161/01. RES.87.2.153

17. Cybulsky MI, Iiyama $\mathrm{K}, \mathrm{Li} \mathrm{H}, \mathrm{Zhu} \mathrm{S}$, Chen M, Iiyama M, Davis V, Gutierrez-Ramos JC, Connely PW, Milstone DS. A major role for VCAM-1, but not ICAM-1, in early atherosclerosis. J Clin Invest 2001;107:1255-62. doi: $10.1172 / \mathrm{JCI} 11871$

18. Rapisarda V, Ledda C, Ferrante M, Fiore M, Cocuzza S, Bracci M, Fenga C. Blood pressure and occupational exposure to noise and lead $(\mathrm{Pb})$ : A cross-sectional study. Toxicol Ind Health 2016;32:1729-36. doi: 10.1177/0748233715576616

19. Yücesoy B, Turhan A, Üre M, Imir T, Karakaya A. Effects of occupational lead and cadmium exposure on some immunoregulatory cytokine levels in man. Toxicology 1997;21;123:143-7. doi: 10.1016/S0300-483X(97)00107-8

20. Machoń-Grecka A, Dobrakowski M, Kasperczyk A, Birkner E, Pryzwan T, Kasperczyk S. The effect of subacute lead exposure on selected blood inflammatory biomarkers and angiogenetic factors. J Occup Health 2018;60:369-75. doi: 10.1539/joh.2017-0307-OA

21. Chmurzyńska A. The multigene family of fatty acid-binding proteins: function, structure and polymorphism. J Appl Genet 2006;47:39-48. doi: 10.1007/BF03194597

22. Başar O, Akbal E, Köklü S, Tuna Y, Koçak E, Başar N, Tok $\mathrm{D}$, Erbiș H, Senes M. Increased H-FABP concentrations in nonalcoholic fatty liver disease. Possible marker for subclinical myocardial damage and subclinical atherosclerosis. Herz 2013;38:417-22. doi: 10.1007/s00059-012-3714-x

23. Beysel S, Kizilgul M, Ozbek M, Çalışkan M, Kan S, Apaydın M, Ozcelik O, Cakal E. Heart-type fatty acid binding protein levels in elderly diabetics without known cardiovascular disease. Clin Interv Aging 2017;12:2063-8. doi: 10.2147/ CIA.S137247

24. Centers for Disease Control and Prevention (CDC). Blood Lead Levels---United States, 1999--2002. MMWR. May 27, 2005; 54(20):513-516.

25. ACGIH $^{\circledR}$ Threshold Limit Values $\left(\mathrm{TLVs}^{\circledR}\right)$ and Biological Exposure Indices $\left(\mathrm{BEIs}^{\circledR}\right)$. Appendix B, 2012. [displayed 28 January 2019]. Available at https://www.nsc.org/Portals/0/ Documents/facultyportal/Documents/fih-6e-appendix-b.pdf

26. Aliyev V, Kayaalti Z, Kaplan B, SoylemezogluT. Effect of GST polymorphisms on as levels of placental and maternal biological samples. Toxicol Lett 2012;211:S43-S216. doi: 10.1016/j.toxlet.2012.03.261

27. Valentino M, Rapisarda V, Santarelli L, Bracci M, Scorcelletti M, Di Lorenzo L, Cassano F, Soleo L. Effect of lead on the levels of some immunoregulatory cytokines in occupationally exposed workers. Hum Exp Toxicol 2007;26:551-6. doi: 10.1177/0960327107073817

28. Kasperczyk A, Dobrakowski M, Czuba ZP, Horak S, Kasperczyk S. Environmental exposure to lead induces oxidative stress and modulates the function of the antioxidant defense system and the immune system in the semen of males 
with normal semen profile. Toxicol Appl Pharmacol 2015;284:339-44. doi: 1016/j.taap.2015.03.001

29. Karbek B, Ozbek M, Bozkurt NC, Ginis Z, Gungunes A, Unsal IO, Cakal E, Delibası T. Heart-Type Fatty Acid Binding Protein (H-FABP): Relationship with arterial intima-media thickness and role as diagnostic marker for atherosclerosis in patients with impaired glucose metabolism. Cardiovasc Diabetol 2011;10:37. doi: 10.1186/1475-2840-10-37

30. Tanaka T, Sohmiya KI, Kitaura Y, Takeshita H, Morita H, Ohkaru Y, Asayama K, Kimura H. Clinical evaluation of point-of-care-testing of heart-type fatty acid-binding protein (H-FABP) for the diagnosis of acute myocardial infarction. J Immunoassay Immunochem 2006;27:225-38. doi: $10.1080 / 15321810600734919$

31. Jeong JH, Seo JH, Ahn JY, Kim KH, Seo JY, Kim MJ, Lee HT, Park PW. The prognostic value of serum levels of hearttype fatty acid binding protein and high sensitivity $\mathrm{C}$ reactive protein in patients with increased levels of amino-terminal pro-B type natriuretic peptide. Ann Lab Med 2016;36:420-6. doi: 10.3343/alm.2016.36.5.420

32. Davies MJ, Gordon JL, Gearing AJH, Pigott R, Woolf N, Katz D, Kyriakopoulos A. The expression of the adhesion molecules ICAM- 1, VCAM- 1, PECAM, and E-selectin in human atherosclerosis. J Pathol 1993;171:223-9. doi: $10.1002 /$ path. 1711710311

33. Nahrendorf M, Keliher E, Panizzi P, Zhang H, Hembrador S, Figueiredo JL, Aikawa E, Kelly K, Libby P, Weissleder R. 18F-4V for PET-CT imaging of VCAM-1 expression in atherosclerosis. JACC Cardiovasc Imaging 2009;2:1213-22. doi: 10.1016/j.jcmg.2009.04.016

34. Johnston-Cox HA, Koupenova M, Ravid K. A2 adenosine receptors and vascular pathologies. Arterioscler Thromb Vasc Biol 2012;32:870-8. doi: 10.1161/ATVBAHA.112.246181

35. Futterman LG, Lemberg L. Novel markers in the acute coronary syndrome: BNP, IL-6, PAPP-A. Am J Crit Care 2002;11:168-72. PMID: 19690642

36. Cung H, Aragon MJ, Zychowski K, Anderson JR, Nawarskas J, Roldan C, Sood A, Qualls C, Campen MJ. Characterization of a novel endothelial biosensor assay reveals increased cumulative serum inflammatory potential in stabilized coronary artery disease patients. J Transl Med 2015;13:99. doi: 10.1186/s12967-015-0457-5

\section{Učinci profesionalne izloženosti olovu na izabrane upalne biomarkere}

Pri izloženosti toksičnim metalima poput olova, utvrđivanje razina olova i upalnih citokina (IL-6, IL-10 i TNF- $\alpha$ ) ključno je za rano otkrivanje bolesti. Cilj je ovoga ispitivanja bio osmisliti model za rano otkrivanje upala i ateroskleroze u mladih radnika profesionalno izloženih olovu dok se još nisu pojavili klinički znakovi i simptomi. Zahvaljujući tomu, liječnici bi mogli pravovremeno započeti liječenje. Ispitivanje je obuhvatilo 49 metalskih radnika izloženih olovu i 50 neizloženih administrativnih radnika (kontrolna skupina) koji su bili podvrgnuti imunološkim testovima na citokine (IL-6, IL-10 i TNF- $\alpha$ ) i na markere ateroskleroze (h-FABP i VCAM-1), toksikološkomu testu na olovo te rutinskim biokemijskim testovima (ALT, AST, kreatinin) u Bolnici za profesionalne i okolišne bolesti u Ankari 2017. Razine olova u krvi korelirale su s razinama IL-6, IL-10 odnosno TNF- $\alpha(r=0,469, r=0,521$, odnosno $r=0,279, p<0,01)$, ali nisu značajno utjecale na razine h-FABP odnosno VCAM-1. 